\title{
Grazing History Affects Willow Communities in a Montane Riparian Ecosystem
}

\author{
Kathryn A. Holland, ${ }^{1}$ Wayne C. Leininger, ${ }^{2}$ and M. J. Trlica ${ }^{2}$ \\ Authors are ${ }^{1}$ Graduate Research Assistant and ${ }^{2}$ Professors, Department of Forest, Rangeland and Watershed Stewardship, \\ Colorado State University, Fort Collins, CO 80523.
}

\begin{abstract}
This study was conducted to compare data from 12 grazed and ungrazed areas and to examine the impacts of grazing treatments on a montane willow community during an 11-year period. Data were collected on willow canopy cover, species diversity, height, and stem density in a montane riparian ecosystem between 1988 and 1999 from 4 grazing treatments: long-term grazing (since the early 1900s), long-term grazing exclusion (exclosures built in the 1950s), recent grazing (sections of exclosures opened in 1988), and recent grazing exclusion (exclosures built in 1988). Willow canopy cover increased significantly for all treatments through time, with the recent grazing exclusion treatment becoming similar to that of the long-term exclusion treatment within 5 years. Species diversity was greatest in the long-term grazed treatment. Willow height averaged over treatments increased from 1988 to $1997(P=0.0001)$, but did not increase significantly after that. Height in the long-term exclosure averaged over time from 1988 to 1997 was 1.5 times greater than in the long-term grazing treatment. Stem density of willows was significantly greater in the recent exclosure than in the long-term exclosure $(P=0.008,180 \%)$ and recent grazing treatments $(P=0.02$, $120 \%)$. Recent grazing exclusion resulted in the greatest increase in canopy cover, height growth, and stem density during the 11 years of study, indicating that these variables respond positively to removal of livestock grazing. Results suggest that continued long-term grazing exclusion may lead to a closed canopy, lower willow species diversity, reduction in new stem height growth, and reduced stem recruitment. Information on the dynamics of willow growth under different grazing treatments should help resource managers determine appropriate livestock utilization levels in similar riparian areas, and develop management plans for these important ecosystems.
\end{abstract}

\section{Resumen}

El presente estudio se condujo para comparar datos de 12 áreas apacentadas y sin apacentar y examinar los impactos de tratamientos de apacentamiento sobre una comunidad montañosa de "Willow" en un período de 11 años. Los datos colectados fueron cobertura de copa del "Willow", diversidad de especies, altura y densidad de tallos y se tomaron en un ecosistema ribereño montañoso entre 1988 y 1999 provenientes de 4 tratamientos de apacentamiento: apacentamiento a largo plazo (desde inicios de 1900), apacentamiento a largo plazo-exclusión (exclusiones construidas en la década de los 1950), apacentamiento reciente (secciones de las exclusiones abiertas al apacentamiento en 1988) y apacentamiento reciente-exclusión (exclusiones construidas en 1988). La cobertura de copa del "Willow" se incrementó significativamente a través del tiempo en todos los tratamientos, siendo el tratamiento de apacentamiento reciente-exclusión similar al tratamiento de apacentamiento de largo plazo-exclusión, dentro de un periodo de cinco años. La mayor diversidad de especies se observó en el tratamiento de apacentamiento a largo plazo. La altura del "Willow" promediada en todos los tratamientos se incrementó de 1988 a 1997 $(\mathrm{p}=0.0001)$, pero no se incrementó significativamente después de esa fecha. La altura en el tratamiento de apacentamiento a largo plazo-exclusión, promediada a través del tiempo de 1988 a 1997, fue 1.5 veces mayor que en el tratamiento de apacentamiento a largo plazo. La densidad de tallos del "Willows" fue significativamente mayor en el tratamiento de exclusión reciente que en los tratamientos de exclusión a largo plazo $(\mathrm{p}=0.008,180 \%)$ y apacentamiento reciente $(\mathrm{p}=0.02,120 \%)$. En el periodo de 11 años de estudio, el tratamiento de apacentamiento reciente-exclusión resultó el mayor incremento de cobertura de copa, crecimiento en altura y densidad de tallos, indicando que estas variables responden positivamente a la remoción del apacentamiento del ganado. Los resultados sugieren que el continuo apacentamiento a largo plazo-exclusión puede conducir a una cobertura de copa cerrada, una baja diversidad de especies de "Willow", la reducción de crecimiento de los tallos nuevos y una producción de tallos reducida. La información sobre las dinámicas del crecimiento del "Willow" bajo diferentes tratamientos de apacentamiento debe ayudar a los manejadores de los recursos a determinar los niveles apropiados de utilización por el ganado en áreas ribereñas similares y a desarrollar planes de manejo para estos importantes ecosistemas.

Key Words: Salix, willow height, cattle grazing, grazing exclusion, riparian areas

\section{INTRODUCTION}

The Colorado Agricultural Experimental Station and USDA Rangelands Grant Program funded this research.

Correspondence: Wayne Leininger, Dept of Forest, Rangeland and Watershed Stewardship, Colorado State University, Fort Collins, CO 80523. Email: waynel@cnr. colostate.edu

Manuscript received 13 March 2002; manuscript accepted 6 November 2004.
Riparian areas serve important functions for maintaining water quality, stream bank stability, wildlife and fishery habitat, livestock forage, and aesthetics and recreational values for humans (Behnke 1979; Densmore et al. 1987; Green and Kauffman 1989; Hupp and Osterkamp 1996; Pearce et al. 1998). Willows (Salix spp.) are found in riparian zones around the world and are often used in riparian restoration efforts (van 


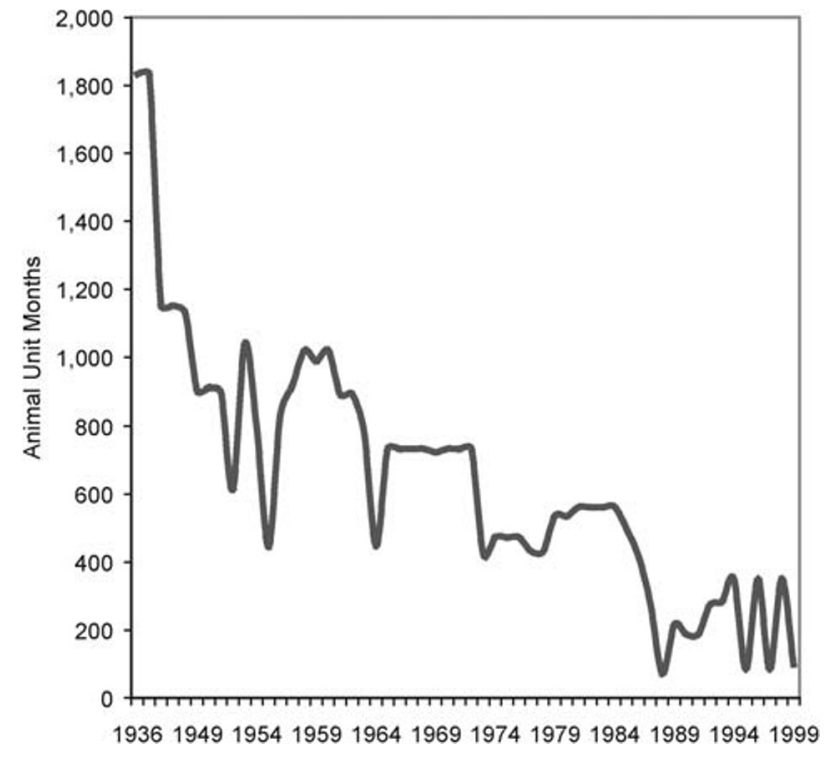

Figure 1. Animal unit months on the Sheep Creek Grazing Allotment since 1936. Source: USFS Sheep Creek C \& H Allotment Management Plan, Red Feather Ranger District, Roosevelt National Forest. Unpublished data.

Splunder et al. 1994) because of their availability, ease of establishment, rapid growth, and relatively low cost (Conroy and Svejcar 1991). Willow stands can function as sediment filters, and their well-developed root systems have been shown to remove nitrogen from runoff (Elowson 1999). Woody canopy cover provided by willows can shade small streams, thereby improving aquatic habitat (Behnke 1979; Stuber 1985), and can also affect understory vegetation through shading and competition (Peck 1999).

It is well known that livestock prefer riparian zones for easy access to water and shade, cooler temperatures, and the more palatable and nutritious vegetation generally found in these areas (Roath and Krueger 1982; Pinchak et al. 1991; Pelster 1998). Willows become a principal source of cattle browse as more palatable herbs are depleted (Kauffman et al. 1983; Kovalchik and Elmore 1992; Pelster 1998), and willow consumption increases as forage stubble heights decrease (Pelster 1998; Clary and Leininger 2000).

Heavy livestock use can negatively impact riparian willows through trampling, browsing, and breaking their lower branches as cattle seek forage and shade (Schulz and Leininger 1990). Managers often wish to reestablish willows on degraded riparian sites to stabilize streambanks, restore hydrologic processes (Svejcar et al. 1992), provide habitat, and shade the stream. However, they often lack information on willow growth responses to altered environmental conditions (Kovalchik and Elmore 1992) and erosion processes (van Splunder et al. 1994). Currently, there are relatively few long-term studies (i.e., greater than 5 years) (Schultz and Leininger 1990; Green and Kauffman 1995; Clary 1999) that have examined the effects of livestock use on willow community structure and canopy cover. This study was conducted to compare data from 12 grazed and ungrazed areas and to examine the impacts of grazing treatments on willow canopy cover, species diversity, height, and stem densities during an 11-year period.

\section{MATERIALS AND METHODS}

\section{Study Area}

This study was conducted in the Sheep Creek riparian ecosystem in northern Larimer County, approximately $75 \mathrm{~km}$ northwest of Fort Collins, Colorado. The Sheep Creek watershed is located in the Roosevelt National Forest at approximately $2500 \mathrm{~m}$ elevation, lat $40^{\circ} 56.46^{\prime} \mathrm{N}$ and long $105^{\circ} 39.55^{\prime} \mathrm{W}$. Soils are classified as fluvaquents, which are characterized by extremely variable layers ranging from sandy loam to clay loam stratified within thick layers of sand or clay (USDA-SCS and Forest Service 1980). Soils along Sheep Creek exhibit an A horizon up to $20 \mathrm{~cm}$ thick with a $3 \%$ to $5 \%$ slope (McEldowney et al. 2002). A water table commonly occurs at a depth of about $30 \mathrm{~cm}$ or less at some time during spring and summer, and within the rooting zone during most of the growing season. Sheep Creek is a 4- to 5-m-wide headwater stream (Schulz and Leininger 1990) with an annual hydrograph that exhibits 2 distinct peaks. The first peak occurs in early spring with snowmelt, and the second in late July or August when about $1.5 \mathrm{~m}^{3} \cdot \mathrm{sec}^{-1}$ of water is released from the Eaton Reservoir $5 \mathrm{~km}$ above the site for approximately 35 days. The exact date of summer release may vary depending on seasonal precipitation (Stednick and Fernald 1999). Construction of the Eaton Reservoir in the early 1900s likely resulted in reduced peak flows in Sheep Creek; however, no records were taken on stream flow prior to dam construction (E. Wilkes, personal communication, July 2000). Limited weather data are available between 1988 and 1995, and no data are available after 1995. These limited records indicate that mean annual precipitation is approximately $406 \mathrm{~mm}$, and average long-term precipitation for the growing season (May-September) is $236 \mathrm{~mm}$. Longterm average daily temperature range is $0^{\circ}-25^{\circ} \mathrm{C}$ during the growing season (National Oceanic and Atmospheric Administration 2000).

The dominant vegetational overstory along Sheep Creek is comprised of various willow species including planeleaf willow (Salix planifolia Pursch var. planifolia), Geyer willow (Salix geyeriana Andersson), peachleaf willow (Salix amygdaloides Andersson), coyote willow (Salix exigua Nuttall ssp. exigua var. exigua), and yellow willow (Salix lutea Nuttall). Other common woody species at Sheep Creek include shrubby cinquefoil (Potentilla fruticosa (Pursh) A. Love.) and lodgepole pine (Pinus contorta Dougl. ex Loud). Important herbaceous understory species include sedges (Carex spp.), Baltic rush (Juncus balticus Willd.), Kentucky bluegrass (Poa pratensis L.), tufted hairgrass (Deschampsia caespitosa L.), and numerous forbs (e.g. Taraxacum officinale Weber, Trifolium repens L.) (Schulz and Leininger 1990; Popolizio et al. 1994).

The Sheep Creek Allotment, which includes 1052 ha of grazeable range, was very heavily grazed prior to the $1940 \mathrm{~s}$ (Fig. 1). Willow stems are generally not visible in photographs taken at Sheep Creek in the 1940s, although willow crowns were present (Schulz and Leininger 1990). Vegetative reproduction of existing willow crowns is possible, although natural willow establishment is not likely at Sheep Creek due to reduced peak flows and minimal channel movement (Scott et al. 1996). This study focuses on the vegetative dynamics of an existing willow community. 


\section{Experimental Design}

Between 1956 and 1959, the US Forest Service (USFS) and Colorado Division of Wildlife established 3 livestock grazing exclosures along Sheep Creek to aid in the recovery of vegetation. These exclosures encompass a total area of about 40 ha and approximately $2.5 \mathrm{~km}$ of riparian zone. In 1988, 2 additional treatments encompassing approximately 10 ha collectively were created by opening 3 sections of the exclosures established in 1956 to grazing, and by creating 3 new exclosures in grazed areas. These 2 new treatments allowed for comparisons between long-term grazing or exclosure (since 1956), and recent grazing or exclosure (since 1988). Thus, 3 replications of 4 treatments exist: 1) long-term grazing, 2) longterm grazing exclusion, 3 ) recent grazing in previously excluded areas, and 4) recent exclusion from grazing. Treatments were examined in 7 time intervals from 1988 to 1999.

Livestock grazing has been progressively reduced on the Sheep Creek Allotment from about 1800 animal unit months (AUMs) in the early 1900s to 99 AUMs in 1999 (Fig. 1); however, wildlife grazing has not been quantified. Herbaceous forage utilization for the study site was estimated at about $65 \%$ of current year's growth in 1985 and 1986 (Schulz and Leininger 1990), when approximately 500 AUMs were allocated to cattle grazing. Clary (1999) defined utilization on a cold, mountain meadow riparian system in central Idaho as $25 \%=$ light and $50 \%=$ moderate. Shaw (1992) defined streamside forage utilization as $20 \%-35 \%=$ light, $36 \%-$ $55 \%=$ moderate, $56 \%-75 \%=$ heavy, and $>75 \%=$ very heavy. Thus, 65\% utilization in 1985 and 1986 may be considered heavy by these standards. Stocking rates have declined since utilization was estimated in 1986 (Fig. 1), and in 1991, the USFS classified the ecological condition at Sheep Creek as excellent and the range forage value condition as good (USFS, unpublished data). By USFS standards, recovery of the Sheep Creek Grazing Allotment from the intense grazing pressure experienced prior to 1956 had been successful. However, it was expected that the long-term effects of heavy livestock grazing and exclusion would still be evident after 11 years because of livestock preference for riparian areas (Ames 1977; Bryant 1982; Roath and Krueger 1982). Livestock grazing is currently season long, from 21 June until 30 September.

\section{Vegetation Sampling}

Data on willow canopy cover, species type, stem height, and stem density were collected between 1988 and 1999 from 3 subplots that were randomly established within each replication of the 4 grazing treatments. Two steel fence posts marked adjacent corners of the subplot and 2 open-ended, $1-\mathrm{m}^{2}$ frames were placed open end to open end on the soil surface on the outside of the 2 posts. A $1-\mathrm{m}$ rod was placed between the open ends of the frames creating two, $1-\mathrm{m}^{2}$ sub-subplots at each sample location. Subplots were numerically tagged on established posts to ensure continuity of plot identification and data collection throughout the study.

Data were collected in August 1988 and 1989, and then every 2nd year until 1999. In 1994, 2 subplots in 1 replication of the long-term exclosure treatment were flooded by beaver activity and were excluded from further sampling. Data were recorded by species and included the number of stems per willow clump (a clump was identified as stems arising from the ground making up the central axis of the plant; all willow stems in a clump were counted if half of the clump was within the frame), height of the tallest stem for each clump, and canopy cover. Willow canopy cover was obtained by ocular estimation (to the nearest $1 \%$ ) using a $20 \mathrm{~cm} \times 50 \mathrm{~cm}$ frame placed in each of the 4 corners of the subplots.

\section{Data Analyses}

The study was designed as a randomized complete block with 3 replicates and repeated measures over time. Grazing treatment was the independent variable, willow canopy cover, height, and stem density were the dependent variables, and willow community diversity was a derived variable. Species diversity was calculated using the Shannon's diversity index $\left(H^{\prime}=-\right.$ SUM $\left[\left\{P_{i}\right\} \times \ln \left\{P_{i}\right\}\right]$, where $\left\{P_{i}\right\}$ is the total number of species, and $\ln \left\{P_{i}\right\}$ is the $\log$ of this number) (Shannon and Weaver 1949), and compared across treatments using analysis of variance (ANOVA) (SAS Institute 1999). Canopy cover for individual willow species was used as the measure of abundance for calculating diversity.

Data from 1- $\mathrm{m}^{2}$ sub-subplots were averaged, and the resulting data from the three, $2-\mathrm{m}^{2}$ subplots in each treatment were then averaged for each replicate in each year data were analyzed using the mixed procedure in SAS software (SAS Institute 1999), in the context of a repeated-measures ANOVA. Fixed factors were year, treatment, and their interaction. Random factors were block, treatment by block, and year by block interactions. Statistical significance was considered at the $\alpha=0.05$ level. The least square means option in "proc mixed" within SAS, which is a $t$ test for all pairwise differences (SAS Institute 1999), was used to determine differences among grazing treatments and years.

Residual error was modeled as autoregressive, lag 1 (AR[1]) or spatial power (SP[POW]), and the appropriate model was considered statistically significant at $\alpha=0.05$. Residual scatter plots were examined to determine if statistical assumptions for ANOVA were met. Least square means and standard errors are reported in the original scale for most data, but comparisons of least square means were made in square root transformations for stem density, and arc sine transformations for canopy cover to meet ANOVA assumptions of homogeneous variances.

\section{RESULTS AND DISCUSSION}

\section{Willow Canopy Cover}

Analysis of willow canopy cover showed that the treatment by year interaction was significant $(P=0.0001)$. Canopy cover in the long-term exclosure and recently grazed treatment were similar $(P=0.30)$ and were significantly greater $(P<0.05)$ in 1988 than cover in the recent exclosure and long-term grazed treatments, and this pattern remained similar throughout the study (Fig. 2).

Willow canopy cover significantly increased $(P<0.05)$ between 1988 and 1999 for all treatments (Fig. 2). Canopy cover in 1988 was lowest in the long-term grazing treatment $(16 \%)$, but cover in this treatment increased more than 3 -fold by 1999 to approximately $65 \%$. This increase in willow canopy cover in the long-term grazing treatment likely resulted from a gradual reduction of AUMs over time (Fig. 1), although 


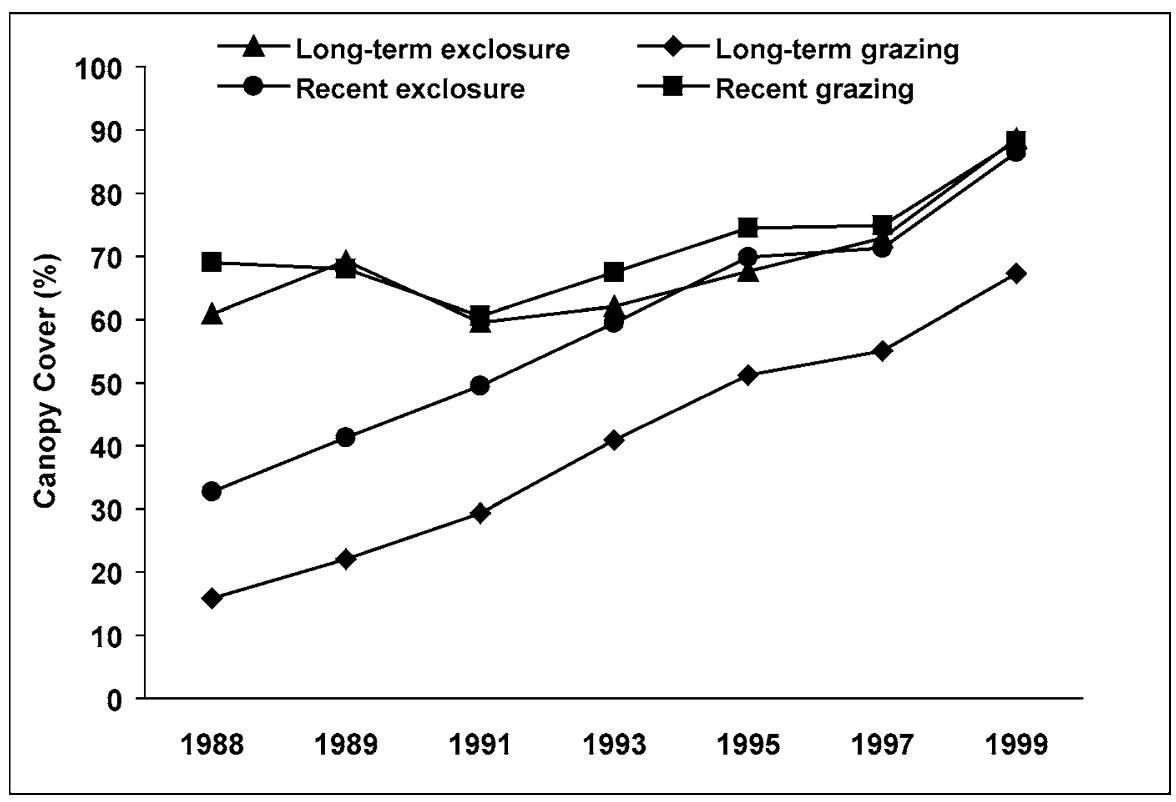

Figure 2. Willow canopy cover by year and grazing treatment from 1988 to 1999 at Sheep Creek, Colorado. Values shown are least squares means \pm 1 standard error. Means are presented in original scale but analyses of data were for an arc sine transformation to meet analysis of variance assumptions.

livestock did continue to congregate in the riparian zone. However, willow canopy cover remained greater in the longterm exclosures than long-term grazed areas throughout the course of the study (Fig. 2).

The recent exclosure had approximately 33\% willow canopy cover in 1988, but it took only about 5 years (i.e., 1993) for canopy cover in this treatment to reach levels similar to those in recently grazed and long-term exclosure treatments (Fig. 2). Results indicate that livestock exclusion for 5 years had a short-term impact on willow canopy cover, allowing cover to increase to levels similar to those found in areas where livestock had been excluded for more than 30 years. The relatively rapid increase in willow cover in the recent exclosure is indicative of the resilient nature of riparian communities once disturbance is removed. These results are similar to other studies in the western United States (Rickard and Cushing 1982; Case and Kauffman 1997; Clary 1999).

Table 1. Shannon-Weaver diversity index based on willow cover and willow richness from 1989-1999 for 4 grazing treatments at Sheep Creek, Colorado.

\begin{tabular}{|c|c|c|c|c|c|c|c|c|}
\hline \multirow[b]{2}{*}{ Year } & \multicolumn{4}{|c|}{ Diversity index } & \multicolumn{4}{|c|}{ Willow richness } \\
\hline & $\mathrm{LG}^{1}$ & RE & LE & $R G$ & $\mathrm{LG}$ & $\mathrm{RE}$ & LE & $\mathrm{RG}$ \\
\hline 1989 & 0.64 & 0.60 & 0.85 & 0.66 & 3 & 4 & 3 & 2 \\
\hline 1991 & 1.20 & 0.52 & 0.98 & 0.73 & 5 & 5 & 4 & 3 \\
\hline 1993 & 1.36 & 0.55 & 0.79 & 0.63 & 5 & 4 & 3 & 2 \\
\hline 1995 & 1.22 & 0.96 & 0.92 & 0.88 & 5 & 5 & 3 & 3 \\
\hline 1997 & 1.15 & 0.88 & 0.87 & 0.73 & 4 & 4 & 3 & 3 \\
\hline 1999 & 1.09 & 0.80 & 0.93 & 0.72 & 3 & 2 & 3 & 3 \\
\hline
\end{tabular}

${ }^{1} \mathrm{LG}$ indicates long-term grazed; RE, recent exclosure; LE, long-term exclosure; $\mathrm{RG}$, recently grazed.
Although increased willow cover may be beneficial for aquatic habitat (Stuber 1985) and wildlife habitat, especially for bird species (Ammon and Stacey 1997), a completely closed canopy may contribute to a decline in total understory diversity including graminoids, forbs, and native species (Peck 1999). Reduction of willow canopy cover by light to moderate livestock browsing may be one method for improving understory species richness and diversity, provided grazers can reach the mid or upper layer of willow leaves.

\section{Willow Species Diversity}

In the Sheep Creek willow community, the most heavily disturbed treatment, long-term grazing, exhibited significantly greater diversity of willows from 1991 to the end of the study $(P<0.05)$ than the recent grazing and exclosure treatments. Initially, long-term grazing exhibited lower willow species diversity than the long-term exclosure (Table 1).

S. planifolia contributed the greatest coverage at the study site regardless of grazing treatment, and occurred in all 4 sites. Although the Sheep Creek riparian community type has not been classified, the dominance of $S$. planifolia suggests that this willow community had reached a relatively stable seral stage (Padgett et al. 1989); however, little is known about successional trends involving S. planifolia (Youngblood et. al 1985). S. geyeriana was also prevalent in all 4 treatments through the course of the study, but its coverage was most abundant in the long-term exclosure. Two or 3 willow species may account for a major portion of the composition of some willow stands (Hudak and Ketchson 1992), as was the case with S. planifolia and $S$. geyeriana at Sheep Creek. Recently grazed areas and the parent treatment, long-term exclosure, also supported S. lutea, whereas the recent exclosure and its parent treatment, longterm grazing, commonly included 2 additional species, $S$. amygdaloides and S. exigua (Table 1). These observations 


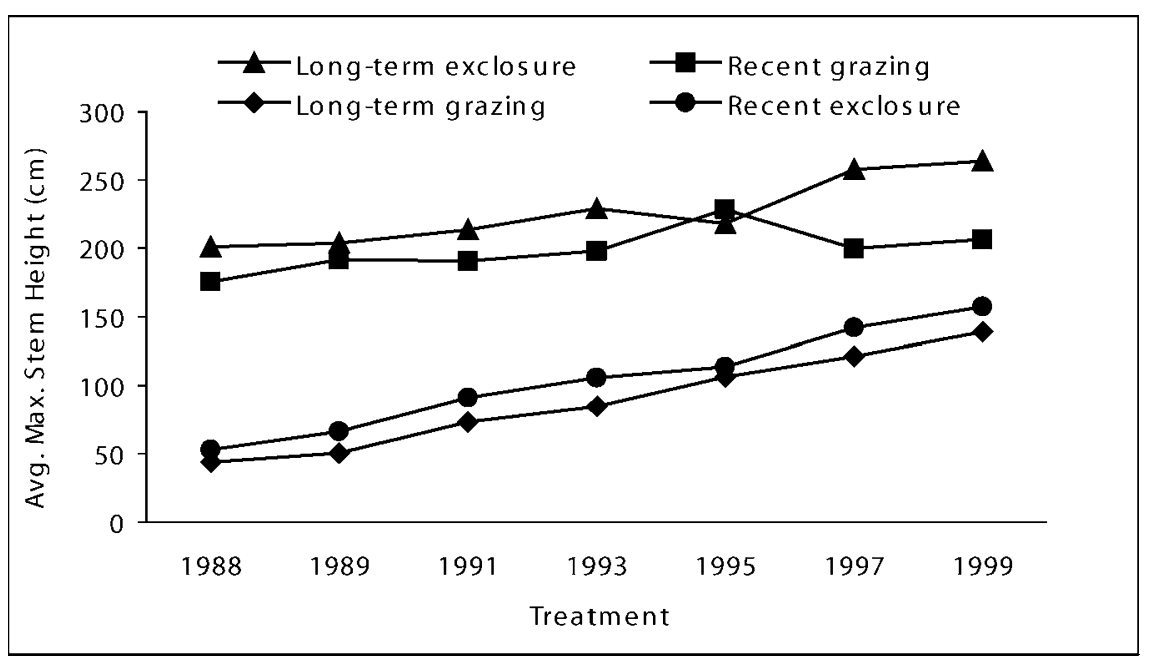

Figure 3. Willow stem height by year and grazing treatment from 1988 to 1999 at Sheep Creek, Colorado. Values shown are least squares means \pm 1 standard error.

suggest that long-term exclusion could influence willow community species composition, with protected stands supporting fewer species than browsed stands.

The long-term grazing treatment supported a greater percentage of canopy coverage from $S$. amygdaloides than the other 3 treatments. S. exigua was prevalent in the recent exclosure and long-term grazed treatments until 1995, and then was absent after that time. It is likely that $S$. exigua is a pioneer species (Padgett et al. 1989), declining in abundance in more mature, protected stands of willows. In the absence of fluvial disturbance, long-term grazing may keep willows in an earlier seral stage, as evidenced by the greater proportion of S. exigua in this treatment. S. amygdaloides was present with grazing disturbance, but decreased in canopy cover with reduced grazing pressure.

\section{Willow Height}

Analysis of willow stem height showed no significant treatment by year interaction $(P=0.21)$. However, both treatment $(P=0.007)$ and year $(P=0.0001)$ main effects were significant. Stem height in the recently grazed treatment averaged during 11 years of study was similar $(P=0.35)$ to stem height of the long-term exclosure treatment from which it was established. Likewise, stem height in the recent exclosure treatment was similar $(P=0.60)$ to the long-term grazed treatment from which it was established (Fig. 3). However, these pairs of treatments were statistically different $(P<0.05)$ from each other, with the recent grazing and long-term exclosure treatments averaging more than twice the stem height of the recent exclosure and long-term grazing treatments. Thus, the effects of the 2 long-term treatments on maximum stem height remained apparent after 11 years of changed grazing management.

Contrary to these results, Billig (1992) expected that willow heights, 3 to 5 years posttreatment change, would become similar between recent grazing and long-term grazing treatments, and between recent exclosure and long-term exclosure treatments. Such a response assumes grazing damage to previously protected willows and increased stem growth in newly excluded willow stands. This discrepancy might be an artifact of sampling protocol, which included measuring the average maximum stem height per clump. Willow stems were older and taller in 1988 within the recent grazing treatment than those in the recent exclosure. Therefore, stems in the recent grazing treatment were often beyond the reach of livestock when the treatment was established, considering $150 \mathrm{~cm}$ as an average browse height for cattle (L.R. Rittenhouse, personal communication, November 2000). It is unlikely that livestock browsed the higher willow branches, supporting the results of no change between recently grazed and long-term ungrazed treatments. Browsing by moose, elk, and deer, which are capable of jumping exclosure fences, may also have affected these results, and although wildlife use in these exclosures was not quantified, evidence of wildlife browsing within them was apparent during the course of the study.

Through time, maximum stem height per clump averaged over the 4 treatments increased $63 \%$ from 118 to $192 \mathrm{~cm}$, although there were no significant increases in average maximum stem height in the last 3 years of the study (Fig. 3). The greatest height increase occurred between 1995 and 1997 $(11 \%)$ when averaged across grazing treatments (Fig. 3). Precipitation was above average in 1995 (634 $\mathrm{mm}$ ) and AUMs were greatly reduced in 1995 and 1997 (Fig. 1), which likely contributed to increased willow growth. However, precipitation levels in riparian areas may be less important than in uplands because of the availability of groundwater. These results concur with those of Lamman (1994), who found that willow heights generally increased with light grazing $(30 \%$ grazing intensity) to moderate $(60 \%$ grazing intensity) defoliation at Sheep Creek.

\section{Willow Stem Density}

Analysis of willow stem density showed no significant treatment by year interaction $(P=0.08)$. However, both treatment $(P=0.03)$ and year $(P=0.01)$ main effects were significant. Willow stem density was similar in both grazed treatments and the long-term exclosure treatment when averaged during the 11 years of study (Fig. 4). Stem density in the recent exclosure 


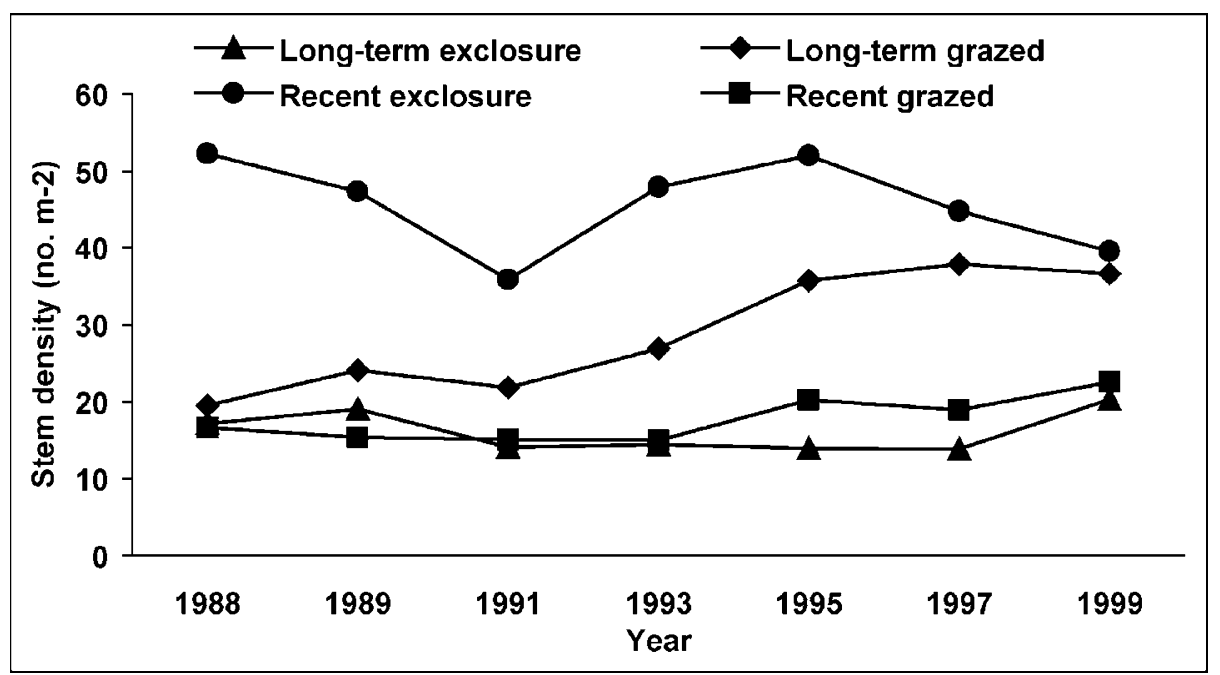

Figure 4. Willow stem density by year and grazing treatment from 1988 to 1999 at Sheep Creek, Colorado. Values shown are least squares means \pm 1 standard error. Means are presented in original scale but analyses of data were for a square root transformation to meet analysis of variance assumptions.

was $180 \%$ greater than the long-term exclosure, $120 \%$ greater than the recently grazed treatment, and $57 \%$ greater than the long-term grazing treatment.

Billig (1992) did not find a significant change in willow stem numbers among treatments, but we expected that stem density in the recent exclosure would decrease over time as willow stands in this treatment aged and self-thinned. Plant species, especially woody species such as willows, show a strong correlation between size and stem density, with larger plants having fewer stems per unit area (Spurr and Barnes 1980). It was expected that willow stem density in the recent exclosure would become more similar to that in the long-term exclosure over time; however, the recent exclosure consistently maintained the greatest stem density, whereas density was lowest in the longterm exclosure when averaged during the 11 years of the study. Results suggest that long-term livestock exclusion can result in decreased willow stem density through plant aging and selfthinning, and without stem recruitment, willow communities may decline in the riparian ecosystem (Kauffman et al. 1983). Schulz and Leininger (1990) concluded that continued but reduced cattle grazing at approximately $65 \%$ herbaceous usage did not limit willow density at Sheep Creek (i.e., vegetative stem growth occurred with reduced grazing pressure). This appears to be true for the current study, although the recent exclosures had greater willow stem density than expected.

\section{MANAGEMENT IMPLICATIONS}

The greatest increases in canopy cover and stem recruitment of montane riparian willows were observed in the long-term grazing treatment following reduced stocking rates. Recent grazing exclusion also resulted in increased canopy cover of willows to levels found in long-term exclosure. Recent exclusion also resulted in stem recruitment; however, stem density did not reach levels found in long-term exclusion. It is possible that more time is needed to find evidence of self-thinning in this willow community, whereas variables such as willow canopy cover and height respond more quickly to changes in grazing management. Willows in the recent exclosure were short enough for continued wildlife browsing, unlike the recent grazing treatment in which 30 years of prior exclusion produced tall willows beyond the browsing height of cattle $(P<0.05)$. Long-term grazing exclusion resulted in taller willows with greater canopy cover, but stem density remained lower than in grazed areas.

Results from this study suggest that livestock removal can be effective for initiating rapid recovery (e.g., 5 years) of willow canopy cover and stem height, but that livestock removal may not be necessary for recovery. In fact, long-term exclusion may lead to a closed canopy, reduced willow vegetative stem recruitment, and reduced species diversity. As an alternative, managers may want to consider reduced stocking rates to improve degraded willow stands in similar riparian systems. Results also suggest that light to moderate season-long cattle grazing, rather than complete exclusion, is compatible with increased canopy cover, species diversity, willow stem height, and stem recruitment as long as there are existing willow crowns and adequate soil, water table depth, and fluvial geomorphic processes.

These results can help resource managers to improve grazing plans, define Best Management Practices for the optimal use of willows in riparian zones, and plan for multiple use and improvement in the functional condition of riparian areas simultaneously. Healthy willow communities should provide improvements in streambank stability, water quality, and fish and wildlife habitat. With proper management, multiple uses in riparian areas that include light to moderate livestock grazing could be beneficial to these important ecosystems, while serving human and wildlife needs.

\section{ACKNOWLEDGMENTS}

Special thanks to Mark Brick, Gary Frasier, and Mike Scott for reviewing drafts of this manuscript. In addition, help in data collection by Mike Villa, Paul Billig, and Laura Peck is gratefully acknowledged. 


\section{LITERATURE CITED}

Ames, C. R. 1977. Wildlife conflicts in riparian management grazing. In: Importance, preservation and management of riparian habitat: A symposium. US Department of Agriculture Forest Service General Technical Report RM-43. Fort Collins, C0. p 49-51.

Ammon, E. M., and P. B. Stacey. 1997. Avian nest success in relation to past grazing regimes in a montane riparian system. Condor 99:7-13.

BehNKE, R. J. 1979. Values and protection of riparian ecosystems. In: Mitigation symposium. US Department of Agriculture Forest Service General Technical Report RM-65. US Department of Agriculture Forest Service Rocky Mountain Forest and Range Experiment Station, Fort Collins, C0. p 164-167.

BILLIG, P. S. 1992. Cattle grazing on willows and overstory/understory relationships in a montane riparian community [MS thesis]. Fort Collins, CO: Colorado State University. $98 \mathrm{p}$

Bryant, L. D. 1982. Response of livestock to riparian zone exclusion. Journal of Range Management 35:780-785.

CaSe, R. L., And J. B. Kauffman. 1997. Wild ungulate influences on the recovery of willows, black cottonwood, and thin-leaf alder following cessation of cattle grazing in northeastern Oregon. Northwest Science 71:115-126.

CLARY, W. P. 1999. Stream channel and vegetation responses to late spring cattle grazing. Journal of Range Management 52:218-227.

Clary, W. P., and W. C. Leininger. 2000. Stubble height as a tool for management of riparian areas. Journal of Range Management 53:562-573.

ConRoY, S. D., AND T. J. SveJcAR. 1991. Willow planting success as influenced by site factors and cattle grazing in northeastern California. Journal of Range Management 44:59-63.

Densmore, R. V, B. J. Nelland, J. C. Zasada, and M. A. Masters. 1987. Planting willow for moose habitat restoration on the North Slope of Alaska, USA. Arctic and Alpine Research 19:537-543.

Elowson, S. 1999. Willow as a vegetation filter for cleaning of polluted drainage water from agricultural land. Biomass and Bioenergy 16:281-290.

Green, D. M., and J. B. Kauffman. 1989. Nutrient cycling at the land-water interface: the importance of the riparian zone. In: R. E. Gresswell, B. A. Barton, and J. L. Kershner [eds.]. Practical approaches to riparian resource management: An educational workshop. BLM-MT-PT-89-001-4351. Billings, MT: USDI-BLM. p 61-68.

Green, D. M., and J. B. Kauffman. 1995. Succession and livestock grazing in a northeastern Oregon riparian ecosystem. Journal of Range Management 48: 307-313.

Hudak, H. G., AND G. L. KetchSON. 1992. Willow community types as influenced by valley bottom and stream types. In: W. P. Clary, E. D. McArthur, D. Bedunah, and C. L. Wambolt [compilers]. Proceedings of the Symposium on Ecology and Management of Riparian Shrub Communities. INT-289. US Department of Agriculture Forest Service General Technical Report. Ogden, UT. p 16-17.

Hupp, C. R., AND W. R. Osterkamp. 1996. Riparian vegetation and fluvial geomorphic processes. Geomorphology 14:277-295.

Kauffman, J. B., W. C. Krueger, and M. Vavra. 1983. Impacts of cattle on streambanks in Northeastern Oregon. Journal of Range Management 36: 683-685.

KovalChiK, B. L., and W. C. Elmore. 1992. Effects of cattle grazing systems on willow-dominated plant associations in central Oregon. In: W. P. Clary, E. D. McArthur, D. Bedunah, and C.L. Wambolt [compilers]. Proceedings of the Symposium on Ecology and Management of Riparian Shrub Communities. US Department of Agriculture Forest Service General Technical Report. INT-289. Ogden, UT. p 111-119.

Lamman, J. S. 1994. Effects of season and intensity of defoliation on two important montane riparian species [MS thesis]. Fort Collins, CO: Colorado State University. $118 p$

McEldowney, R. R., M. Flenniken, G. W. Frasier, M. J. Trlica, and W. C. Leininger. 2002. Sediment movement and filtration in a riparian meadow following cattle use. Journal of Range Management 56:367-373.

National Oceanic and Atmospheric Administration. Available at: http//www.noaa.gov. Accessed 5 April 2000.
Padgett, W. G., A. P. Youngblood, and A. H. Winward. 1989. Riparian community type classification of Utah and Southeastern Idaho. US Forest Service Intermountain Region R4-Ecol-89-01. US Department of Agriculture Forest Service, Intermountain Region. Ogden, UT. 191 p.

Pearce, R. A., G. W. Frasier, M. J. Trlica, W. C. Leininger, J. D. Stednick, and J. L. Sмітн. 1998. Sediment filtration in a montane riparian zone under simulated rainfall. Journal of Range Management 51:309-314.

PECK, L. E. 1999. Grazing history and overstory canopy affect understory diversity in a montane riparian ecosystem [MS thesis]. Fort Collins, C0: Colorado State University. $100 \mathrm{p}$.

Pelster, A. J. 1998. Steer diets and livestock management in a montane riparian zone [MS thesis]. Fort Collins, CO: Colorado State University. $85 \mathrm{p}$.

Pinchak, W. E., R. H. Hart, M. A. Smith, and J. W. Waggoner, JR. 1991. Beef cattle distribution patterns on foothills range. Journal of Range Management 44: 267-275.

Popolzzio, C. A., H. Goetz, and P. L. Chapman. 1994. Short-term response of riparian vegetation to four grazing treatments. Journal of Range Management 47: 48-53.

RiCKARD, W. H., AND C. E. CUSHING. 1982. Recovery of streamside woody vegetation after exclusion of livestock grazing. Journal of Range Management 35: 360-361.

Roath, L. R., and W. C. Krueger. 1982. Cattle grazing influence on a mountain riparian zone. Journal of Range Management 35:100-103.

SAS InStitute. 1999. SAS/STAT Version 8.0 for Windows. Cary, NC: SAS Institute.

Schulz, T. T., AND W. C. LeINIngER. 1990. Differences in riparian vegetation structure between grazed areas and exclosures. Journal of Range Management 43 : 295-299.

Scott, M. L., J. M. Friedman, and G. T. Auble. 1996. Fluvial process and the establishment of bottomland trees. Geomorphology 14:327-339.

Shannon, C. E., AND W. WeAver. 1949. The mathematical theory of communication. Urbana, IL: University of Illinois Press.

Shaw, N. L. 1992. Recruitment and growth of Pacific willow and sandbar willow seedlings in response to season and intensity of cattle grazing. In:W. P. Clary, E. D. McArthur, D. Bedunah, and C. L. Wambolt [compilers]. Proceedings of the Symposium on Ecology and Management of Riparian Shrub Communities. General Technical Report INT-289. US Department of Agriculture Forest Service. Ogden, UT. p 130-137.

Spurr, S. H., and B. V. Barnes. 1980. Forest ecology. New York, NY: John Wiley \& Sons, Inc.

Stednick, J. D., and A. G. Fernald. 1999. Nitrogen dynamics in stream and soil waters. Journal of Range Management 52:615-620.

StuBER, R. J. 1985. Trout habitat, abundance, and fishing opportunities in fenced vs. unfenced riparian habitat along Sheep Creek, Colorado. In: R. R. Johnson, C. D. Ziebell, D. R. Patton, P. F. Ffolliott, and R. H. Hamre [technical coordinators]. Riparian ecosystems and their management: Reconciling conflicting uses. First North American Riparian Conference. General Technical Report RM-120. US Department of Agriculture Forest Service. Fort Collins, C0. p 310-314.

Svejcar, T. J, G. M. Riegel, S. D. Conroy, and J. D. Trent. 1992. Establishment and growth potential of riparian shrubs in the Northern Sierra Nevada. In: W. P. Clary, E. D. McArthur, D. Bedunah, and C. L. Wambolt [compilers]. Proceedings of the Symposium on Ecology and Management of Riparian Shrub Communities. General Technical Report INT-289. US Department of Agriculture Forest Service. Ogden, UT. p 151-154.

USDA-SCS and Forest Service 1980. Soil survey report. Larimer County Area, Colo. Fluvaquent 33 soil series. Washington, DC: US Government Printing Office.

van Splunder, I., H. Coops, And M. M. Schoor. 1994. Tackling the bank erosion problem: (Re-)introduction of willows on riverbanks. Water Science Technology 29:379-381.

Youngblood, A. P., W. G. Padgett, and A. H. Winward. 1985. Riparian community type classification of Eastern Idaho-Western Wyoming. R4-Ecol-85-01. US Forest Service Intermountain Region. Denver, C0. 78 p. 